\title{
КРИМІНАЛЬНЕ ПРОВАДЖЕННЯ ЩОДО ЗАСТОСУВАННЯ ПРИМУСОВИХ ЗАХОДІВ МЕДИЧНОГО ХАРАКТЕРУ: ПРИЗНАЧЕННЯ ПСИХІАТРИЧНОЇ ЕКСПЕРТИЗИ ТА ОСОБЛИВОСТІ ПРЕДМЕТА ДОКАЗУВАННЯ
}

\section{Ряшко О. В.}

\section{ВСТУП}

У Конституції України визначено, що людина, ії життя і здоров’я, честь і гідність, недоторканність і безпека визнаються найвищою соціальною цінністю, а права й свободи людини та їх гарантії визначають зміст і спрямованість діяльності держави. Більше того, держава відповідає перед людиною за свою діяльність, утвердження і забезпечення прав та свобод людини є їі головним обов'язком.

За таких умов залишається актуальним дотримання вимог закону у кримінальних провадженнях щодо застосування примусових заходів медичного характеру, адже громадяни мають рівні конституційні права i свободи та є рівними перед законом і державою, незважаючи на ознаки раси, колір шкіри, політичні, релігійні й інші переконання, стать, етнічне та соціальне походження, майновий стан, місце проживання, мовні чи інші ознаки. Зміни до деяких законодавчих актів України щодо надання психіатричної допомоги стосуються й чинних правових положень вітчизняного кримінального процесуального законодавства, у яких визначено порядок застосування примусових заходів медичного характеру.

Під час кримінального провадження виникають питання, вирішення яких потребує використання наукових, технічних та інших спеціальних знань, а також умінь i навичок, набутих у результаті професійної діяльності, які використовуються 3 метою збирання доказової інформації про кримінальне правопорушення.

Одним 3 напрямів протидії зростання рівня злочинності в державі $\epsilon$ забезпечення принципу невідворотності кримінальної відповідальності. У цьому аспекті важливим є залучення експерта слідчим, прокурором, слідчим суддею, судом та ефективне використання результатів судових експертиз.

Проведення ефективного досудового розслідування неможливе без застосування спеціальних знань. Наукові здобутки сучасності дають змогу на високому рівні проводити експертні дослідження та надавати відповіді на питання, які донедавна залишалися без відповідей, що $\epsilon$ вкрай важливим для вирішення завдань досудового розслідування. 


\section{1. Призначення психіатричної експертизи у кримінальних провадженнях щодо застосування примусових заходів медичного характеру}

Насамперед необхідно зазначити, що осудність та вік особи $\epsilon$ передумовами кримінальної відповідальності, якій передує свідомий вольовий вибір, що включає розуміння соціального значення злочинних дій або бездіяльності та передбачення їх наслідків. Вибір варіанту поведінки являє собою результат взаємодії зовнішньої ситуації 3 особливостями особи, зокрема з її психічним станом. При цьому психічний стан особи впливає на цілий комплекс кримінально-правових проявів суб'єкта: сам факт кримінального правопорушення, його характер, обставини. Осудність нарівні з виною та відповідальністю є центральною методологічною категорією кримінального права 3 точки зору іi1 фундаментального значення для додержання прав і свобод людини. Тому для точного вирішення питання про визнання особи винною для слідчого, прокурора та судді справді важливо розуміти поняття осудності, неосудності та обмеженої осудності.

У ч. 2 ст. 19 КК України регламентується законодавче визначення поняття неосудності, 3 якого випливає, що неосудною визнається така особа, яка під час вчинення суспільно небезпечного діяння, передбаченого КК України, «не могла усвідомлювати свої дії (бездіяльність) або керувати ними внаслідок хронічної психічної хвороби, тимчасового розладу психічної діяльності, слабоумства або іншого хворобливого стану психіки». Ці положення закону про кримінальну відповідальність прийнято називати формулою неосудності. Ця формула містить як медичні, так і юридичні ознаки. У кримінальному праві така формула отримала найменування змішаної формули неосудності. Осудність, так само як вина та відповідальність, - центральна методологічна категорія права як з погляду іiі фундаментального теоретичного рішення, так і 3 погляду практичної цінності та прикладного значення для додержання прав і свобод людини. Психічний стан особи, яка перебуває під слідством, визначається судово-психіатричною експертизою, яка призначається слідчим після встановлення факту вчинення суспільно небезпечного діяння цією особою.

У статті 9 Міжнародного пакту про громадянські та політичні права зазначено, що кожна людина має право на свободу та особисту недоторканність. Нікого не може бути піддано свавільному арешту чи триманню під вартою. Нікого не може бути позбавлено волі інакше, як на підставах і відповідно до такої процедури, що їх встановлено законом. Тому провадження щодо осіб, до яких застосовуються примусові заходи 
медичного характеру, повинно відповідати вимогам теперішнього часу щодо захисту прав і свобод людини і громадянина України.

Вважається, що застосування примусових заходів медичного характеру $\epsilon$ правом, а не обов'язком суду. Вони застосовуються лише до осіб, які є суспільно небезпечними. Якщо особа страждає на психічну хворобу i вчинила суспільно небезпечне діяння, але за характером вчиненого та за своїм психічним станом не являє собою небезпеки для суспільства і не потребує надання психіатричної допомоги в примусовому порядку, то примусові заходи медичного характеру не застосовуються. У положеннях ч. 1 ст. 94 КК України визначено такі види примусових заходів медичного характеру: 1) надання амбулаторної психіатричної допомоги в примусовому порядку; 2) госпіталізація до психіатричного закладу зі звичайним наглядом; 3) госпіталізація до психіатричного закладу 3 посиленим наглядом; 4) госпіталізація до психіатричного закладу із суворим наглядом.

Для призначення певного виду примусових заходів медичного характеру суд має враховувати три критерії: 1) характер і тяжкість захворювання (медичний критерій); 2) тяжкість вчиненого діяння (юридичний критерій); 3) ступінь небезпечності психічно хворого для себе чи інших осіб (соціальний критерій).

У кримінальному праві України питання щодо застосування примусових заходів медичного характеру (далі - ПЗМХ) та примусового лікування вважаються одними з найбільш складних і комплексних. Це зумовлюється багатогранністю цього інституту, оскільки він перебуває на перехресті юридичних і медичних наук та поєднує в собі елементи як правових, так i соціологічних та медичних галузей знань. Розділ XIV «Інші заходи кримінально-правового характеру» чинного Кримінального кодексу України регламентує підстави, порядок здійснення медичного впливу (примусового психіатричного лікування) всупереч волі хворого. Ці норми покликані захистити суспільство від небезпечних посягань осіб, які страждають на психічні розлади. Такі особи, з одного боку, є соціально небезпечними через їхню вірогідну схильність до вчинення правопорушень та суспільно небезпечних діянь, а 3 іншого - це також найбільш вразлива й найменш захищена в правовому аспекті категорія населення країни. Застосування примусових заходів медичного характеру стосується прав і свобод людини, гарантованих їй Конституцією України, а отже, цей кримінально-правовий інститут потребує чіткої правової регуляції, у зв'язку із чим виникає нагальна необхідність детального 
дослідження окресленої проблематики та вдосконалення кримінальноправових норм ${ }^{1}$.

Окремо слід звернути увагу на особливості судово-психіатричних експертиз. Так, відповідно до ст. 509 КПК України слідчий, прокурор зобов'язані залучити експерта (експертів) для проведення психіатричної експертизи у разі, якщо під час кримінального провадження будуть встановлені обставини, які дають підстави вважати, що особа під час вчинення суспільно небезпечного діяння була в неосудному або обмежено осудному стані або вчинила кримінальне правопорушення в осудному стані, але після його вчинення захворіла на психічну хворобу, яка позбавляє її можливості усвідомлювати свої дії або керувати ними. Такими обставинами, зокрема є:

1) наявність згідно з медичним документом у особи розладу психічної діяльності або психічного захворювання;

2) поведінка особи під час вчинення суспільно небезпечного діяння або після нього або $є$ неадекватною (затьмарення свідомості, порушення сприйняття, мислення, волі, емоцій, інтелекту чи пам'яті тощо).

У разі необхідності здійснення тривалого спостереження та дослідження особи може бути проведена стаціонарна психіатрична експертиза, для чого така особа направляється до відповідного медичного закладу на строк не більше двох місяців. Питання про направлення особи до медичного закладу для проведення психіатричної експертизи вирішується під час досудового розслідування - ухвалою слідчого судді за клопотанням сторони кримінального провадження в порядку, передбаченому для подання та розгляду клопотань щодо обрання запобіжного заходу, а під час судового провадження - ухвалою суду.

Згідно зі ст. 243 КПК України сторона обвинувачення залучає експерта за наявності підстав для проведення експертизи, зокрема за клопотанням сторони захисту чи потерпілого. Поряд із тим сторона захисту має право самостійно залучати експертів на договірних умовах для проведення експертизи, зокрема обов'язкової. Також відповідно до ст. 244 чинного КПК України експерта може залучити слідчий суддя за клопотанням сторони захисту в разі відмови слідчого, прокурора в задоволенні клопотання сторони захисту про залучення експерта. Слідчий суддя застосовує процесуальні санкції у вигляді повернення клопотання особі, яка його подала, у разі недодержання вимог КПК, які висуваються до форми і порядку подання клопотання про призначення судової експертизи.

\footnotetext{
${ }^{1}$ Беклеміщев С.О. Госпіталізація до психіатричних закладів із суворим наглядом як вид примусових заходів медичного характеру. Прикарпатський юридичний вісник. Випуск 1 (16). 2017. С. 136-138.
} 
Ухвала слідчого судді про направлення особи до медичного закладу для проведення психіатричної експертизи або відмова у такому направленні може бути оскаржена в апеляційному порядку.

Приблизний перелік питань, які можна винести на вирішення судовопсихіатричної експертизи, такий: чи виявляє потерпіла особа ознаки хворобливого розладу психічної діяльності, якщо так, то який ступінь його тяжкості? чи перебуває виявлений у потерпілого хворобливий розлад психічної діяльності у причинному зв'язку із вчиненими щодо нього діяннями (діями або бездіяльністю)?

Оскільки у кримінальному провадженні показання свідків і потерпілих $\epsilon$ одним із важливих джерел доказів, оцінка якості свідчень учасників кримінального провадження належить до компетенції суду, а фахівці оцінюють їхній психічний стан, здатність правильно сприймати обставини, які мають значення для встановлення істини у справі, та їх відтворювати. Коло питань, що ставляться перед психіатрами щодо потерпілих, $\epsilon$ ширшим, ніж щодо свідків, стосовно яких з'ясовується, як правило, питання щодо здатності та можливості за станом психічного здоров'я правильно сприймати та відтворювати події, свідками яких вони були. У зв'язку із цим з'ясовуються питання, чи не страждав свідок на психічне захворювання в період подій, з приводу яких він дає пояснення, чи міг він правильно сприймати зазначені факти та їх відтворювати у своїх поясненнях. Крім того, щодо потерпілих з'ясовуються питання розуміння характеру та значення дій, вчинених проти них, здатність протистояти таким діям, що має значення для правової оцінки дій підозрюваного чи обвинуваченого ${ }^{2}$. Особливий процесуальний порядок призначення експертизи передбачає обов'язкове обмеження конституційних прав i свобод громадян, у тому числі права на недоторканність особи (ст. 29 Конституції України). Тому подібні обмеження під час проведення психіатричної експертизи повинні мати досить обгрунтовані фактичні й правові підстави.

Призначення такої експертизи повинне: по-перше, бути зумовленим важливістю обставин, які відомі або можуть бути відомі особі і які підлягають доказуванню у кримінальному провадженні, без чого встановлення істини у справі $\epsilon$ ускладненим; по-друге, мати під собою достатні фактичні підстави, а саме для критичного ставлення до пояснень особи через наявність обставин, котрі свідчать про особливості поведінки особи, що можуть вказувати на наявність у неї психічних розладів (неадекватна поведінка у побуті, немотивована збудженість,

\footnotetext{
${ }^{2}$ Кузьменко В. Окремі питання, що виникають під час призначення психіатричної експертизи у кримінальному процесі. Слово Національної школи суддів України. 2013. № 2. С. 25-29.
} 
непослідовність i суперечливість пояснень під час кримінального провадження, нерозуміння загальноприйнятих i суспільно визначених категорій, надмірно низький рівень загальноосвітніх знань тощо); по-третє, наявність інформації про перенесення особою захворювань і травм, що супроводжувались зміною поведінки; інформації про перебування особи на обліку у психіатра або про звільнення її від військової служби тощо.

Окремі ознаки зазначених явищ або їх сукупність, а також наявність відповідної інформації про особливості психіки будь-кого зі згаданих учасників кримінального провадження можуть стати підставою для призначення психіатричної або психолого-психіатричної експертизи, але у всякому разі іiі призначення має бути об'єктивно необхідним і чітко регламентуватися кримінальним процесуальним законодавством.

У ст. 46 КПК України з метою забезпечення захисту прав учасників кримінального провадження слід передбачити право захисника на витребування конфіденційної інформації щодо підзахисного за його особистою згодою або згодою його опікуна чи піклувальника. Законодавче врегулювання питань призначення та проведення психіатричної чи психолого-психіатричної експертиз сприятиме гарантованому захисту прав і свобод учасників кримінального провадження.

Основні категорії фактичних підстав та інформаційних джерел, які вказують на доцільність проведення судово-психіатричної експертизи: 1) обставини, котрі свідчать про те, що особа була раніше чи перебуває під наглядом психіатра; особа госпіталізувалася і лікувалася у психіатричній лікарні, визнавалася у зв'язку з психічним захворюванням непридатною до військової служби; особа в іншій справі визнавалася неосудною, перебувала на примусовому психіатричному лікуванні (джерелом інформації будуть відповіді на офіційні запити від відповідних спеціалізованих установ Міністерства охорони здоров'я України (медичні книги, медичні картки, результати психіатричних спостережень та обстежень, матеріали тестування, рішення судів тощо); 2) обставини, що свідчать про особливості поведінки особи, які можуть вказувати на наявність у неї психічного захворювання (джерелом інформації $\epsilon$ суб'єктивне сприйняття та оцінювання слідчим, прокурором поведінки особи); 3) обставини, що випливають з інформації, отриманої із клопотань, заявлених учасниками процесу, про необхідність проведення судовопсихіатричної експертизи (джерелом інформації є документація, зібрана учасником кримінального провадження для обгрунтування відповідного клопотання); 4) обставини, що засвідчують безмотивний характер злочину або скоєння злочину з особливою жорстокістю (джерелом інформації $\epsilon$ матеріали кримінального провадження, наприклад, протоколи слідчих 
(розшукових) дій). Предметом експертизи є визначення психічного стану осіб, яким ії призначено, у конкретні проміжки часу і відносно певних обставин, що мають юридичне значення і цікавлять органи досудового розслідування та суд.

Можна констатувати, що, виходячи із нині чинного законодавства та принципів кримінального права, примусові заходи медичного характеру із окремими кримінально-правовими наслідками (реальне відбування покарання, звільнення від відбування покарання, примусове лікування, спеціальна конфіскація), за наявності підстав для застосування їх обох можуть застосовуватися разом (одночасно); щодо інших кримінальноправових наслідків (звільнення від покарання, звільнення від кримінальної відповідальності), то якщо є підстави і для їхнього застосування, і для застосування ПЗМХ, то лише перші із них повинні бути застосовані; нарешті, мають місце випадки, коли саме ПЗМХ лише або насамперед (до одужання) можуть застосовуватися замість інших кримінально-правових наслідків (реальне відбування покарання, звільнення від відбування покарання, примусові заходи виховного характеру). Однак з огляду на сутність та мету застосування ПЗМХ, такі є самостійним кримінальноправовим наслідком, а тому передбачення у чинному КК України можливості застосування їх поряд 3 іншими кримінально-правовими наслідками, що виступають формами реалізації кримінальної відповідальності, $є$ порушенням прав особи та принципів кримінального права. Тому варто було б законодавцеві як внести відповідні зміни в наявні норми, так i закріпити правила застосування чи ПЗМХ, чи інших кримінально-правових наслідків, коли є підстави для застосування їх обох ${ }^{3}$.

Від ретельності підготовки матеріалів для проведення експертизи залежить іï повнота і всебічність, надійність експертного висновку. Цілу низку дій має право проводити лише орган, що призначив експертизу, i заборонено перекладати ї проведення на експертів. Це передусім стосується збирання матеріалів, що підлягають дослідженню. Всі важливі для судження про психічний стан особи дані слідчий повинен зібрати не тільки шляхом його допиту, але й допиту його родичів, близьких, знайомих та інших осіб. Здійснюючи проведення експертизи, експерт (експерти) повинен дати відповідь на питання про ступінь і характер психічного захворювання такої особи. Після проведення всіх необхідних досліджень експерт складає висновок, в якому повинно бути зазначено: коли, де, ким (прізвище, освіта, спеціальність, учений ступінь і звання, посада експерта), на якій підставі була проведена експертиза, хто був

\footnotetext{
${ }^{3}$ Панчак О.Г. Примусові заходи медичного характеру та інші кримінально-правові наслідки: окремі проблеми застосування. Часопис Київського університету права. 2015. № 2. С. 305-309.
} 
присутній під час проведення експертизи, запитання, що були поставлені експертові, які матеріали експерт використав та які провів дослідження, мотивовані відповіді на поставлені запитання.

\section{2. Особливості предмета доказування у кримінальному провадженні щодо застосування примусових заходів медичного характеру}

Примусові заходи медичного характеру не є заходами примусу, що застосовуються від імені держави за вироком суду, вони не несуть функції покарання особи за вчинене кримінальне правопорушення. Такі заходи $\epsilon$ системою лікувальних, медично-профілактичних та медично-реабілітаційних заходів, що здійснюються у спеціальних лікувальних закладах психіатричного профілю і застосовуються до чітко визначеної категорії осіб виключно судом і відповідно до закону. Суб'єктами застосування таких заходів виступають фізичні особи, що досягли віку кримінальноправового впливу, але стан їхнього психічного здоров'я не дає змогу застосувати взагалі або на певний час заходи кримінального покарання за вчинені ними суспільно небезпечні діяння ${ }^{4}$.

Під час досудового розслідування у кримінальному провадженні щодо застосування примусових заходів медичного характеру мають бути всебічно, повно й об'єктивно встановлені такі обставини, як:

1) час, місце, спосіб та інші обставини вчинення суспільно небезпечного діяння або кримінального правопорушення; у разі доказування обставин, які утворюють подію злочину чи суспільно небезпечного діяння, належить встановлювати елементи об'єктивної сторони складу злочину, що відбуваються у певному місці, часі та певним способом. Перелік таких ознак визначається відповідною нормою закону України про кримінальну відповідальність, що визнає злочином конкретне суспільно небезпечне діяння. Спосіб вчинення суспільно небезпечного діяння або кримінального правопорушення $\epsilon$ комплексом дій 3 підготовки, вчинення та приховування, що здійснюється в певній послідовності та призводить до певного злочинного наслідку;

2) вчинення цього суспільно небезпечного діяння або кримінального правопорушення цією особою; 3 огляду на те, що особа, яка вчинила суспільно небезпечне діяння на момент його вчинення перебувала у стані неосудності, тобто не могла усвідомлювати свої дії та керувати ними, така особа кримінальну відповідальність за вчинене нею діяння нести не може, отже, не є суб'єктом злочину;

\footnotetext{
${ }^{4}$ Колесник В.А. Процесуальна визначеність повноважень слідчого, прокурора, суду в кримінальному провадженні щодо застосування примусових заходів медичного характеру. Вісник Академї адвокатури Украӥни. № 2 (28). 2013. С. 40-45.
} 
3) наявність у цієї особи розладу психічної діяльності в минулому, ступінь і характер розладу психічної діяльності чи психічної хвороби на час вчинення суспільно небезпечного діяння або кримінального правопорушення, чи на час досудового розслідування; наявність у особи психічного розладу в минулому є підставою припустити, що на момент вчинення суспільно небезпечного діяння особа перебувала у такому стані, коли не усвідомлювала свої дії та не могла ними керувати. Тому для встановлення цієї обставини слід звернутись із відповідним запитом до психоневрологічного диспансеру за місцем проживання особи та до лікувального закладу, якщо особа раніше проходила лікування у зв'язку із розладом психічної діяльності чи психічною хворобою. Ступінь і характер розладу психічної діяльності чи психічної хвороби на час вчинення суспільно небезпечного діяння або кримінального правопорушення, чи на час досудового розслідування встановлюється лікарями шляхом проведення судово-психіатричної експертизи;

4) поведінка особи до вчинення суспільно небезпечного діяння або кримінального правопорушення і після нього; такі обставини можна встановити шляхом проведення допиту близьких та родичів особи, яка вчинила суспільно небезпечне діяння або кримінальне правопорушення. Крім того, слід враховувати, що потерпілий, а також свідки вчинення кримінального правопорушення можуть надати інформацію про дії особи, щодо якої проводиться кримінальне провадження;

5) небезпечність особи внаслідок ії психічного стану для самої себе та інших осіб, а також можливість спричинення іншої істотної шкоди такою особою; небезпечність особи для самої себе та інших осіб зумовлюється психічним розладом, який має така особа, чи психічною хворобою, на яку вона страждає, та може бути встановлена виключно шляхом проведення судово-психіатричної експертизи;

6) характер і розмір шкоди, завданої суспільно небезпечним діянням або кримінальним правопорушенням. У такій категорії кримінальних проваджень доказуванню підлягають обставини, які характеризують наслідки діяння неосудної особи (характер і розмір збитку, заподіяного суспільно небезпечним діянням, а також розміри витрат закладу охорони здоров'я на стаціонарне лікування потерпілого від злочинного діяння) ${ }^{5}$.

Що ж стосується необхідності встановити наявність у цієї особи розладу психічної діяльності в минулому, поведінку особи до вчинення суспільно небезпечного діяння і після нього, то такі обставини, на наш погляд, є

\footnotetext{
5 Законодавче забезпечення правоохоронної діяльності. Методичні рекомендації щодо особливого досудового розслідування кримінальних проваджень стосовно застосування примусових заходів медичного характеру Київ. 2019. С. 367-378.
} 
допоміжними, їх можна включити до предмета доказування для перевірки достовірності інших доказів, що свідчать про неосудність особи 6 .

Встановлення характеру i розміру заподіяної шкоди передбачає з'ясування характеру і розміру матеріальної, фізичної та моральної шкоди. При цьому розмір матеріальної шкоди можна встановити шляхом призначення товарознавчої експертизи. Відшкодування збитків у провадженнях такої категорії має певну специфіку. Адже особа, яка вчинила суспільно небезпечне діяння у стані неосудності, за наявності у неї майна може нести матеріальну відповідальність за рахунок цього майна. Якщо ж у неосудної особи майна немає, то матеріальну відповідальність за заподіяну іï діями шкоду повинні нести інші особи, на яких за законом ця відповідальність покладається (батьки, опікуни, піклувальники тощо). Необхідність доказування зазначених обставин виникає 3 моменту встановлення під час досудового розслідування підстав для здійснення кримінального провадження щодо застосування примусових заходів медичного характеру, і слідчим або прокурором буде прийнята постанова про зміну порядку досудового розслідування.

Загальновідомим є той факт, що чимало суспільно небезпечних діянь вчиняють особи, які перебувають у стані неосудності, а кримінальних правопорушень - осудні особи, які захворіли на психічну хворобу до постановлення вироку. Остання із вказаних категорій осіб не обділена увагою міжнародної та національної спільноти, свідченням чого $\epsilon$ законодавчі акти, спрямовані на дотримання їхніх прав i законних інтересів. У контексті кримінальних процесуальних правовідносин указані завдання, безумовно, поширено й на зазначених осіб, що потребує здійснення правозастосовниками всіх необхідних заходів з охорони їхніх прав і свобод, а також застосування належної правової процедури, зокрема сприяння прийняттю законного й обгрунтованого рішення про примусові заходи медичного характеру (ПЗМХ) ${ }^{7}$.

У цій категорії кримінальних проваджень доказуванню підлягають обставини, які характеризують наслідки діяння неосудної особи (характер і розмір збитку, заподіяного суспільно небезпечним діянням, а також розміри витрат закладу охорони здоров'я на стаціонарне лікування потерпілого від злочинного діяння).

\footnotetext{
6 Лукашкіна Т.В. Предмет доказування у провадженні щодо застосування примусових заходів медичного характеру. Правові та інституиійні механізми забезпечення розвитку Украӥни в умовах європейської інтеграції : матеріали Міжнародної науково-практичної конференції (м. Одеса, 18 травня 2018 р.) У 2-х т. Т. 2 / відп. ред. Г.О. Ульянова. Одеса : Видавничий дім «Гельветика», 2018. С. 315-319.

7 Черніснко А. Процесуальні права особи, щодо якої вирішується питання про застосування примусових заходів медичного характеру в контексті законодавчих змін. Вісник Національної академії прокуратури Украӥни. 2018. № 2(54). С. 35-45.
} 
Слідчий під час розслідування проваджень із можливістю застосування примусових заходів медичного характеру не повинен визначати розмір процесуальних витрат, а також ті обставини, які могли би вплинути на правову санкцію (обставини, що впливають на ступінь тяжкості, пом'якшують чи обтяжують покарання тощо). Цілком очевидно, що ці обставини встановлювати не потрібно, адже щодо особи можуть бути застосовані примусові заходи медичного характеру. Водночас відомо, що у разі видужання особи суд своєю ухвалою припиняє застосування примусових заходів медичного характеру, а така ухвала $є$ підставою для проведення досудового розслідування чи судового розгляду 8 .

Запобіжні заходи до особи, стосовно якої передбачається застосування примусових заходів медичного характеру або вирішувалося питання про їх застосування, є засобами впливу на таку особу з метою обмеження ii свободи або встановлення за нею нагляду. Відповідно до положень, передбачених ч. 1 ст. 508 КПК України, до такої особи можуть бути застосовані судом такі запобіжні заходи: 1) передання на піклування опікунам, близьким родичам чи членам сім'ї для обов'язкового лікарського нагляду; 2) поміщення до психіатричного закладу в умовах, що виключають іiі небезпечну поведінку. Запобіжні заходи застосовуються судом до особи 3 моменту встановлення факту розладу психічної діяльності чи психічної хвороби за загальними правилами.

Тобто предмет доказування у кримінальному провадженні щодо застосування примусових заходів медичного характеру має низку особливостей, де не ставиться питання про винуватість обвинуваченого у вчиненні кримінального правопорушення, а йдеться про вчинення певною особою суспільно небезпечного діяння, а умисел, мета i мотив $\epsilon$ елементами суб'єктивної сторони саме злочину та встановлюються лише щодо осудної особи.

\section{ВИСНОВКИ}

Під час досудового розслідування і судового розгляду кримінального провадження (кримінальної справи) здебільшого виникають питання, вирішення яких неможливе без залучення до розслідування осіб із різними спеціальними знаннями.

Судова експертиза - це дослідження експертом на основі спеціальних знань матеріальних об'єктів, явищ і процесів, які містять інформацію про

\footnotetext{
${ }^{8}$ Торбас О.О. Загальна характеристика застосування примусових заходів медичного характеру за чинним КПК України. Науковий вісник Міжнародного гуманітарного університету. Сер.: Юриспрудениія. 2013. № 62. Том 2. С. 135.
} 
обставини справи, що перебуває у провадженні органів досудового розслідування або суду.

Використання спеціальних знань у межах слідчих (розшукових) дій допустимо лише за наявності двох умов. По-перше, результатом такого дослідження $\epsilon$ не висновок на основі спеціальних знань, а наочний факт (наприклад, невидимий слід, виявлений за допомогою хімічних, оптичних й інших засобів); по-друге, встановлений факт повинен мати загальнодоступний характер, виступати як очевидний результат проведеного дослідження для всіх учасників слідчої (розшукової) дії, які не мають спеціальних знань.

Сама експертна діяльність виходить за межі кримінального судочинства, $\epsilon$ самостійною та регулюється спеціальними нормативними актами. Вирішення питання про спосіб проведення експертизи входить у спеціальну компетенцію експерта. Слідчий і суд не вправі втручатися в дослідження, які проводяться експертом.

В умовах реформування кримінального процесуального законодавства України треба вирішити одне із важливих питань - вдосконалення нормативної регламентації порядку призначення судової експертизи у кримінальному провадженні.

Кримінальні процесуальні норми, які сформульовані в конкретних статтях КПК України, підлягають точному їх дотриманню під час застосування всіма учасниками кримінального провадження, а для правильності такого застосування вони повинні мати чітко визначене формулювання вкладених у них думок законодавця. Окрім того, положення, що сформульовані у певній статті кримінального процесуального закону, повинні кореспондуватися 3 положеннями інших статей КПК, в яких розкривається порядок їх застосування у певній або іншій ситуації кримінального провадження.

\section{АНОТАЦІЯ}

Застосування примусових заходів медичного характеру покликане захистити суспільство від небезпечних посягань осіб, які страждають психічними розладами, та забезпечити підтримання належного рівня безпеки в соціумі. Отже, сутність примусових заходів медичного характеру, за загальноприйнятою думкою, полягає у тому, щоб забезпечити безпеку психічно хворих осіб і захистити суспільство від їхніх суспільно небезпечних діянь. 3 метою реалізації цих завдань держава повинна забезпечити безпеку кожного i суспільства загалом від небезпечних посягань таких осіб, не допустити вчинення особами 3 
психічними аномаліями злочинних суспільно небезпечних діянь, оскільки їхній спосіб життя і вчинки свідчать про таку можливість.

Небезпечність осіб із психічними розладами проявляється також в особливостях формування мотивів вчинення суспільно небезпечних діянь, що зумовлює несподіваний, непередбачуваний характер їхньої поведінки. До того ж для зазначених осіб характерна нездатність вчитися на своїх помилках, тобто вони не використовують минулий досвід, вчиняючи нові суспільно небезпечні діяння.

Необхідність контролю за поведінкою такого контингенту осіб з боку держави набуває особливої актуальності в соціально-політичній та економічній ситуації в країні, що склалася натепер: підвищений рівень злочинності; безробіття та побутова невлаштованість; конфліктні ситуації, що охопили суспільство; низький освітній, культурний рівень розвитку населення та інші негативні чинники.

\section{ЛІТЕРАТУРА}

1. Беклеміщев С.О. Госпіталізація до психіатричних закладів із суворим наглядом як вид примусових заходів медичного характеру. Прикарпатський юридичний вісник. Випуск 1 (16). 2017. С. 136-138.

2. Кузьменко В. Окремі питання, що виникають під час призначення психіатричної експертизи у кримінальному процесі. Слово Національної школи суддів України. 2013. № 2. С. 25-29.

3. Панчак О.Г. Примусові заходи медичного характеру та інші кримінально-правові наслідки: окремі проблеми застосування. Часопис Київського університету права. 2015/2. С. 305-309.

4. Колесник В.А. Процесуальна визначеність повноважень слідчого, прокурора, суду в кримінальному провадженні щодо застосування примусових заходів медичного характеру. Вісник Академії адвокатури України. № 2 (28). 2013. С. 40-45.

5. Законодавче забезпечення правоохоронної діяльності. Методичні рекомендації щодо особливого досудового розслідування кримінальних проваджень стосовно застосування примусових заходів медичного характеру. Київ. 2019. С. 367-378.

6. Лукашкіна Т.В. Предмет доказування у провадженні щодо застосування примусових заходів медичного характеру. Правові та інституційні механізми забезпечення розвитку України в умовах європейської інтеграції : матеріали Міжнародної науково-практичної конференції (м. Одеса, 18 травня 2018 р.) У 2-х т. Т. 2 / відп. ред. Г.О. Ульянова. Одеса : Видавничий дім «Гельветика», 2018. С. 315-319. 
7. Чернієнко А. Процесуальні права особи, щодо якої вирішується питання про застосування примусових заходів медичного характеру в контексті законодавчих змін. Вісник Національної академії прокуратури України. 2018. 2(54). С. 35-45.

8. Торбас О.О. Загальна характеристика застосування примусових заходів медичного характеру за чинним КПК України. Науковий вісник Міжнародного гуманітарного університету. Сер.: Юриспрудениія. 2013. № 62. Том 2. С. 133-135.

9. Дуфенюк О.М. Досвід Польщі стосовно участі судового експерта у кримінальному провадженні. Науковий вісник ЛьвДУВС. № 1/2018. C. 240-249.

10. Бараняк В., Несімко О. Проблемні питання призначення судових експертиз у кримінальному провадженні. Вісник Національного університету Львівська політехніка. Юридичні науки. 2019. Випуск 22. C. $195-198$.

11. Берш А.Я. Примусові заходи медичного характеру: правова природа та види : автореферат дис. ... канд. юрид. наук : спец. 12.00.08 «Кримінальне право та кримінологія; кримінально-виконавче право». Національний університет «Одеська юридична академія» МОН України. 2017.

12. Книга М. Проблеми правової регламентації провадження та зміни примусових заходів медичного характеру. Підприємництво, господарство i право. 2012. № 3. С. 131-134.

13. Сенченко Н.М. Поняття та особливості процесуального статусу осіб, стосовно яких передбачається застосування примусових заходів медичного характеру. Актуальні проблеми вітчизняної юриспруденції. № 6. Том 1. 2018. С. 171-175.

14. Слободзян А. Правові основи призначення та проведення експертиз у кримінальному провадженні. Юридичний науковий електронний журнал. № 6/2014. С. 224-228.

15. Фаринник В. Особливості формування доказів та доказування у кримінальному судочинстві України. Харків : Фактор, 2013. 96 с.

\section{Information about author:} Ryashko O. V.,

Candidate of Law Sciences, Associate Professor, Associate Professor at the Department of Criminal Procedure and Criminalistics Lviv State University of Internal Affairs 26, Gorodok str., Lviv, 79000, Ukraine 